NBER WORKING PAPER SERIES

\title{
PRICES AND PRICE DISPERSION ON THE WEB: EVIDENCE FROM THE ONLINE BOOK INDUSTRY
}

\author{
Karen Clay \\ Ramayya Krishnan \\ Eric Wolff \\ Working Paper 8271 \\ http://www.nber.org/papers/w8271
NATIONAL BUREAU OF ECONOMIC RESEARCH 1050 Massachusetts Avenue
Cambridge, MA 02138
May 2001

We would like to thank Bo-Han Chen, Yimin Yang, Danny Fernandes, and Kartik Hosanager for excellent research assistance. We would also like to thank: Y. S. Chi of Ingram Book Group for insights on the wholesale market for books; Andy Ross of Cody Books for providing information on wholesale prices; Paul Mozak and Chris Nichols of Borders Group, John Vogus of Allbooks4Less.com, and other industry sources for discussions of the book industry; and Mike Smith and seminar participants at the NBER 2000 Summer Meetings for helpful comments on the paper. The views expressed herein are those of the authors and not necessarily those of the National Bureau of Economic Research.

(C) 2001 by Karen Clay, Ramayya Krishnan and Eric Wolff. All rights reserved. Short sections of text, not to exceed two paragraphs, may be quoted without explicit permission provided that full credit, including (C) notice, is given to the source. 
Prices and Price Dispersion on the Web: Evidence from the Online Book Industry

Karen Clay, Ramayya Krishnan and Eric Wolff

NBER Working Paper No. 8271

May 2001

JEL No. L

\section{ABSTRACT}

Using data collected between August 1999 and January 2000 covering 399 books, including New York Times bestsellers, computer bestsellers, and random books, we examine pricing by thirtytwo online bookstores. One common prediction is that the reduction in search costs on the Internet relative to the physical channel would cause both price and price dispersion to fall. Over the sample period, we find no change in either price or price dispersion. Another prediction of the search literature is that the prices and price dispersion of advertised items or items that are purchased repeatedly will be lower than for unadvertised or infrequently purchased items. Prices across categories of books appear to conform to this prediction, with New York Times bestsellers having the lowest prices as a fraction of the publisher's suggested price and random books having the highest prices. Interestingly, price dispersion does not conform with this prediction, apparently for reasons related to stores' decisions to carry particular books. One reason why we may not observe convergence in prices is because stores have succeeded in differentiating themselves even though they are selling a commodity product. We observe differentiation (or attempted differentiation) by a significant number of firms.

Karen Clay

Heinz School of Public Policy and Management

Carnegie Mellon University

Pittsburgh, PA 15213

kclay@andrew.cmu.edu

Eric Wolff

Graduate School of Industrial Administration

Carnegie Mellon University

Pittsburgh, PA 15213

wolff@andrew.cmu.edu
Ramayya Krishnan

Heinz School of Public Policy and Management

Carnegie Mellon University

Pittsburgh, PA 15213

rk2x@andrew.cmu.edu 


\section{Introduction}

One widely reported prediction is that the availability of low-cost information on price - specifically the rise of comparison-shopping engines - will lead all Internet retailers to charge the same price for mass-produced physical goods and that price will be approximately cost. For instance, in a September 1999 New York Times article, Bob Tedeschi noted "New shopping search engines are being developed quickly, bringing the promise of low prices for consumers and thinner margins for Web retailers." 1 An August 1999 Economist article stated "Fierce competition has forced web companies to slash prices." 2 These statements are based on a Bertrand model of competition and rely on consumers using comparison-shopping engines to become fully informed about book prices.

A second prediction of the search literature is that the prices and price dispersion of advertised items or items that are purchased repeatedly will be lower than for unadvertised or infrequently purchased items. The differences in prices and price dispersion are the result of differences in information. This prediction assumes that individuals might be better informed about prices for some types of books, such as New York Times bestsellers, since on and off-line bookstores frequently advertise their discounts on these books.

The empirical literature has primarily focused on comparisons of price and price dispersion in the Internet and physical channels, saying relatively little about changes in prices or price dispersion over time. Lee (1997) compared pricing of used autos in

\footnotetext{
${ }^{1}$ http://search.nytimes.com/search/daily/bin/fastweb?getdoc+site+site+89051+0+wAAA+internet\%7Eprice ${ }^{2}$ The Economist, August 21, 1999.
} 
Internet and physical channels and found that prices were higher in the Internet channel. This may be due to unobserved quality variation. Bailey (1998) using matched sets of books, compact disks, and software also finds higher prices in the Internet channel for 1996-1997. Brynjolfsson and Smith (1999) on books and compact disks for 1998-99 found that Internet retailers had lower prices, made smaller price adjustments, and had greater or smaller price dispersion than conventional channels, depending on whether prices were weighted by proxies for market share.

Empirical studies testing Stigler's (1961) prediction that advertising that improves price information would cause both price and price dispersion to fall confirm this intuition. Comparisons of the prices of goods such as eyeglasses, optometry services, and prescription drugs in states that permitted or did not permit advertising showed that advertising was associated with lower prices and price dispersion. B $_{\text {More recently Milyo }}$ and Waldfogel (1999) found that increased advertising did lower prices on advertised products, but not overall. They also found that price dispersion was stable or increasing in the short run. Sorenson (2000) examined the posted price of drugs across drugstores in two communities. In line with the predictions of search theory, he finds that average price-cost margin and price dispersion are lower if the prescription is purchased repeatedly than if it is purchased only occasionally. It is notable that none of these papers examines data from the Internet.

The first prediction that low cost price information on the Internet will force price and price dispersion to fall is in tension with a third prediction. The third prediction states that firms will seek to differentiate their products. Firms prefer to be differentiated,

\footnotetext{
${ }^{3}$ See Benham (1972), Cady (1976), Devine and Marion (1979), Feldman and Begun (1978, 1980), Glazer (1981) and Kowka (1984).
} 
because it mutes price competition. Thus with product differentiation, prices may not converge in equilibrium and could in fact diverge.

Several authors have found evidence of product differentiation. In a study of the online travel industry, Clemons, Hitt, and Hann (1998) found agents responded to identical requests with different time/price pairs. This evidence suggests that online ticket agents engaged in significant product differentiation. Clay et al. (1999), using data from April 1999, find indirect evidence that online booksellers were engaging in product differentiation through price, selection, and other nonprice attributes. Although it is not a focus of their paper, Brynjolfsson and Smith (1999) on books and compact disks for 1998-99 also find evidence that is consistent with product differentiation.

To investigate these three predictions, we use data on pricing in the online book industry covering the period August 1999 to January 2000. Automated agents collected data for 399 books from thirty-two online bookstores over twenty-five weeks. The books included New York Times bestsellers, former New York Times bestsellers, computer bestsellers, former computer bestsellers, and random books. The stores included wellestablished Internet retailers such as Amazon, BarnesandNoble.com, and Borders.com as well as smaller Internet retailers such as Wordsworth and BCY Bookloft.

\section{Background}

Although book selling over the Internet began in the 1980s, it started to attract national attention from the press in 1993 (Wilke 1993). The first online stores, not surprisingly, primarily sold computer books. Incredible rates of growth in the number of people with access to Internet and the spread of early web browsers in the early 1990s 
made the book market increasingly attractive to retailers and consumers. The number of stores and the range of books available increased dramatically. In July 1995 Amazon entered the market. The two largest bricks and mortar chains - Barnes and Noble and Borders - began Internet sales in May 1997 and May 1998, respectively.

Several factors have shaped the structure of this industry. Each version of a book title has a unique identifier called an International Standard Book Number (ISBN). ISBN's are important for two reasons. First, the existence of these unique identifiers allowed wholesalers to computerize their catalogs in the late 1980s. Computerized catalogs led to more efficient order processing, benefiting the industry as a whole. The first Internet bookstores built their systems on top of these catalogs. Second, consumers can search by ISBN and be assured that they are getting exactly the same product. In some other commodity markets, firms can hinder comparison shopping by bundling a few items and issuing the bundle a new SKU (stock keeping unit) number. Bundles in the book world, in contrast, would be identified by component ISBNs or would have to be issued a new ISBN by the issuing agency.

Market penetration of online bookstores was 5.4 percent in 1999, up from 1.9 percent in 1998 (Book Industry Study Group, 2000). This is significantly higher than overall retail penetration, which finally reached 1 percent in the fourth quarter of 2000 (United States Census, 2001). Consumers can choose among a large number of Internet bookstores. For instance, Yahoo lists more than one hundred online bookstores. And new stores are opening all of the time. Some of the new entrants are physical stores that are migrating to the web, but many others are new internet-only bookstores. 
Consumers interested in comparing the price of a particular ISBN across many stores can use comparison-shopping engines. For instance, Yahoo lists ten comparisonshopping engines that focus primarily or exclusively on books. Examples include BestBookBuys, DealTime, and AddAll. In addition, consumers can choose from a comparison-shopping engines, such as Yahoo Shopping, MySimon, and PriceScan, that focus on many goods, of which books are only one. Most of the major comparisonshopping engines cover twenty or more U.S.-based online bookstores. For instance, DealTime, BestBookBuys, and PriceScan all search between 20 and 30 stores. Their search set includes major players as well as smaller online booksellers.

Finally, online bookstores face very similar wholesale prices for books. As a result of a recent lawsuits in the book industry, all players with even minimal volume now face very similar wholesale prices for books. Industry sources indicate that very large stores (Amazon, Barnes and Noble, and Borders) may receive additional discounts of up to 7 percent of list price for warehousing books, engaging in advertising campaigns, and waiving the right to returns. Depending on the costs of providing these services, the largest stores may get slightly larger net discounts. All other stores face the same prices for books. (Conversation in November 1999 with Y. S. Chi, COO, Ingram Book Group, Friedman 1999, Bookweb.org 1999, and other industry sources) ! $^{\text {. }}$

\footnotetext{
${ }^{4}$ Other costs that stores face can be divided into infrastructure costs, nonmarginal book specific costs, and order fulfillment costs. We are intentionally ignoring marketing expenditures, since they are effectively discretionary. Infrastructure costs include the costs of maintaining warehouse space, most personnel, and the hardware and software associated with the database, orders, and customer service. Nonmarginal book specific costs are one time setup costs related to the creation of the entry for the book in the database with a scanned photo of the cover, establishing linkages with the supplier database, and other efforts that support creation of the page, placement of the order, and order fulfillment.

Order fulfillment costs together with the wholesale price of the book determine the marginal cost of the book. Stores with significant numbers of orders either outsource order fulfillment or maintain large semi or fully automated warehouses. In discussions with companies, it does not appear that the marginal cost of
} 


\section{Predictions}

Four assumptions about the market underlie the prediction that the availability of low-cost information on price will lead all Internet retailers to charge the same price for mass-produced physical goods and that price will be approximately cost. In the Bertrand model of competition, i) consumers are perfectly informed about firms' prices, ii) goods are identical, iii) firms choose price, iv) firms can supply whatever quantity the market demands at constant marginal cost. (Bertrand, 1883). In such a market, if a firm charges a higher price than a competitor, it faces zero demand. Conversely, if a firm charges a marginally lower price than competitors, it will capture demand for the entire market. Thus, price will fall to the marginal cost of a good, with all firms charging the same price.

The first assumption - that consumers are perfectly informed about firms' prices is particularly strong. Although comparison-shopping engines are common, their market penetration is limited, around 2 percent. ${ }^{\mathrm{b}}$ Reasons for the limited penetration include the fact that comparison-shopping engines tend to be slow and the fact that they are cumbersome to use for a basket of goods. As a result, the vast majority of consumers are relatively uninformed about prices. These consumers may, however, be relatively better informed about prices of certain categories of books. In particular, they may be informed about the prices of New York Times bestsellers, because on and off-line bookstores regularly advertise their discounts on these books.

order fulfillment differs much within or between the two options. Industry estimates of order fulfillment costs, which are traditionally reported as a percentage of the sale price, are $10-15 \%$.

${ }^{5}$ It is important to note that search engines do differ in the amount of information provided and bookstores covered. Thus, even consumers who use a search engine may not have perfect information. 
In most theoretical models, dispersion is driven by imperfect information. Imperfect information can arise in a number of different ways - through ex ante differences across consumers or ex post differences created by the operation of the market. The relationship between information and price, however, hinges on the use of quantity-weighted measures of price. For instance, if more consumers become informed, this may reallocate consumers among existing stores, but it may or may not cause firms to change their prices. Hence, unweighted measures of price may not change. In our empirical work, we work with unweighted measures of price. So even if we believe that consumers are becoming more informed, we may not find corresponding price decreases. The second assumption - that goods are identical - is also fairly strong. Choices of search engine customers indicate that they are willing to pay 5.0 percent more to purchase the same book from Amazon rather than from the low price vendor and 3.1 percent more to purchase the same book from Barnes and Noble or Borders (Brynjolffson and Smith, 2001). Since stores such as Amazon, Barnes and Noble, and Borders have invested heavily in branding and in features such as one-click, book reviews, and recommender systems, it is not entirely surprising that some customers would be willing to pay a premium to purchase from them. The theory literature also predicts that in competitive markets firms will seek to differentiate their products to soften price competition, which could result in price dispersion.

Two other factors suggest that static theoretical models and empirical results from stable markets may not translate neatly into dynamic, volatile market such as the Internet.

\footnotetext{
${ }^{6}$ See Butters (1977), Salop and Stiglitz (1977), Pratt, Wise, and Zeckhauser (1979), Wilde and Schwartz (1979), Varian (1980), Salop and Stiglitz (1982), Burdett and Judd (1983), Benabou (1993), Burdett and Coles (1997), Rauh (1997), Kephart and Greenwald (1998) and Arnold (2000).

${ }^{7}$ See Tirole 1988, Chapter 7 for a discussion of the theoretical literature.
} 
First, huge numbers of new consumers are entering the market. If later adopters tend to be less technologically sophisticated, the effect of their entry may be swamping the effects of the increase in the number of informed consumers. In particular, even if the absolute number of informed consumers is increasing, they may represent a declining fraction of the population. Second, firms are entering and exiting. Burdett and Coles (1997) model an economy with noisy search and repeat purchases where both firms and consumers enter and exit. In equilibrium, younger firms offer lower prices to attract consumers and older firms offer higher prices to existing customers who face switching costs. Thus, average prices and price dispersion could be falling or rising, depending on the interaction among changes in information, the number of customers, and the entry and exit of firms.

\section{Data}

\section{Collection}

Automated agents (spiders) were constructed to collect data from two major comparison-shopping engines and some individual Internet booksellers. The web pages for each book in the sample were downloaded and parsed to extract information on unit price, shipping cost, shipping time, and delivery time. The collection process began around 2 am to minimize the load on the servers and to maximize response rate.

The collection process does not cover the universe of all online stores, but the thirty-two stores in our sample cover the largest United States-based stores. For example

it includes Amazon, BarnesandNoble.com, Borders.com, Buy.com, and Booksamillion. Stores were included if they were covered in one of two major comparison-shopping 
engines - DealTime or PriceScan. The focus here on the impact of comparison-shopping engines and the fact that many stores are represented made it natural to collect data from comparison-shopping engines. We also sent agents to some individual stores to guarantee data from important stores and to determine the accuracy of the information from DealTime and PriceScan.

The sample includes five categories of books: New York Times bestsellers, former New York Times bestsellers, computer bestsellers, former computer bestsellers and a random sample of books in print. New York Times bestsellers were included, because they are widely carried, represent high aggregate sales, and are a focal point for discounts. For the New York Times bestsellers, a new panel of approximately 60 titles is begun each week that includes that week's bestsellers in each of four categories: paperback fiction, paperback nonfiction, hardcover fiction and hardcover nonfiction. When New York Times bestsellers go off of the list, we continue to track them as former bestsellers.

Computer books were included, because they were one of the first categories of books sold on the Internet and remain an important category. In particular, purchasers of computer books might also be early adopters of comparison-shopping engines. While, the New York Times does not maintain a comparable bestseller list for computer books, Amazon.com does. We chose Amazon's bestseller list because of Amazon's high volume of book sales and the generalist (as opposed to specialist) orientation of the site. Thus, the 50 books on the computer bestseller list are likely to be purchased by large numbers of consumers and offered in a large number of stores. Like the New York

\footnotetext{
${ }^{8}$ A complete list of the stores is provided in Table 3.

${ }^{9}$ The number is approximate, because there are often ties for the \#15 spot.
} 
Times bestsellers, a new panel is begun each week and that panel is followed on an ongoing basis.

Random books were included to provide a baseline against which to compare the prices and price dispersion of bestsellers and former bestsellers and to understand pricing for the millions of books not covered by the bestseller lists. The random sample was created by generating random strings of letters of random length and then checking the result against the online Books in Print database until approximately 200 in-print titles

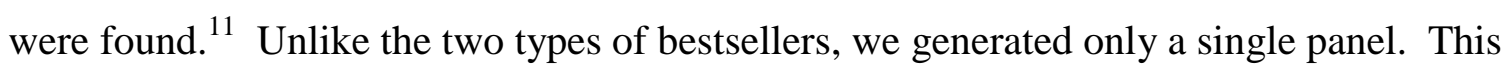
panel has been followed from August 1999 to November 2000.

For the purposes of this paper, we focus on the weekly prices of 399 books between August 1999 and January 2000. Although data collection continued through November 2000, we decided to cut the sample after approximately six months of data collection. We constructed new panels of New York Times bestsellers and computer bestsellers every week. Given computational constraints, however, we chose to focus on just the first, ninth, and seventeenth weeks' bestsellers. ${ }^{12}$ Reported prices are weekly minimums. Data is nominally collected daily, but unavailable servers, problems with the information returned, and changes in search engines, resulted in some data loss. Further problems with disk space forced us to reduce the frequency of collection to every other day for a period in November and December 1999 until the problems could be resolved. Because a bookstore changes the price of a book less than twice on average over the sample period, there is little loss in aggregating to the weekly level.

\footnotetext{
${ }^{10}$ Use of any store's bestseller list raises unavoidable issues of endogeneity.

${ }^{11}$ Some, although technically in print, were not available in any bookstores. After eliminating these, the data set includes 181 random books.
} 


\section{Summary Statistics}

Summary statistics for the data set are presented in Table 1. Our sample includes 181 random books, 136 New York Times bestsellers, and 82 computer bestsellers. If the bestseller lists in weeks one, nine, and seventeen had not overlapped, the sample would have had 180 New York Times bestsellers and 150 computer bestsellers. The number of unique bestsellers was reduced by the fact that bestsellers remained on the lists for 15-16 weeks on average, and thus appear on multiple bestseller lists.

Different categories had different mixes of hardcover/paperback and fiction/nonfiction books. New York Times bestsellers are, by construction, an even mix of hardcover fiction, hardcover nonfiction, paperback fiction, and paperback nonfiction. Departures from the even split are explained by overlap in the bestseller lists from weeks one, nine, and seventeen. In contrast to the New York Times bestsellers, computer bestsellers are predominantly paperback and exclusively nonfiction. Random books are predominately hardcover nonfiction.

Across the five categories, prices show substantial differences between average unit prices and publishers' recommended prices. To facilitate price comparisons, we use normalized price, which is retail price divided by the publisher's recommended price. Average prices are the lowest for New York Times bestsellers and former New York Times bestsellers ( 0.69 and 0.76 of publisher's recommended price), are higher for computer bestsellers and former computer bestsellers (0.78 and 0.79), and are the highest for random books (0.86).

\footnotetext{
${ }^{12}$ We chose weeks one, nine, and seventeen because they are equally spaced throughout the twenty-five week period.
} 
Wholesale prices tend on average to be about 50 percent of the publisher's recommended price. Random books are the exception - they tend to sell for 60 percent of the publisher's recommended price. Average margins are the lowest for New York Times bestsellers (0.19), are higher for former New York Times bestsellers (0.24) and random books (0.26), and are the highest for computer bestsellers and former computer bestsellers ( 0.29 and 0.29$)$. So despite having higher prices than computer books, random books have lower margins.

Measures of price dispersion are inversely related to price. Standard deviation as a percentage of average price is the highest for New York Times bestsellers (28 percent), is lower for former New York Times bestsellers and current computer bestsellers (18 and 16 percent), and is the lowest for former computer bestsellers and random books (14 and 13 percent). The difference between the minimum and maximum prices as a percentage of average price follows this pattern as well.

The last line of Table 1 presents another, more applied measure of price dispersion. Many consumers routinely go to Amazon without checking prices at other stores. Thus, we computed savings that they could have realized by purchasing a book from the lowest cost vendor instead. The average savings as a percentage of Amazon's price ranged from a low of 10 percent for New York Times bestsellers to a high of 25 percent for former New York Times bestsellers. For current New York Times bestsellers, the savings is likely to be about $\$ 1$. For computer books, however, particularly former bestsellers, the amounts can be more significant. For instance, 20 percent savings on a $\$ 40$ computer book is $\$ 8$. 


\section{Prices}

The differences in prices across the five categories of books as well as hardcover and paperback books and fiction and nonfiction books are explored further in Table 2. The dependent variables in regressions are price, normalized price, and normalized margin. ${ }^{13}$ The second regression is slightly easier to interpret than the first, so we will focus on the second regression. The results there show substantial average discounts (17\%-9\%) relative to paperback, nonfiction, random books for current and former New York Times and computer bestsellers, small (2\%) discounts for hardcover books, and more substantial $(6 \%)$ discounts for fiction books. One change is in the pricing of week nine bestsellers. Relative to weeks one and seventeen, the average price of a week nine bestseller has increased 1 percent. Prices are also trending up slightly over time, perhaps because a few stores increased their prices during the holiday season (Christmas is week twenty).

Regressions on gross margins indicate that random books and former bestsellers had gross margins of 25 percent. An average store earned gross margins of 16 percent on New York Times bestsellers and 22 percent on computer bestsellers. The smaller gross margins for New York Times bestsellers than for the computer bestsellers may reflect the relative importance of the two lists and the fact that many stores advertise their discounts on New York Times bestsellers but they do not advertise their discounts on Amazon's computer bestsellers. The slightly larger discount for hardcovers may reflect stores

\footnotetext{
${ }^{13}$ Using price as the dependent variable presumes that stores set prices in absolute dollar terms. In contrast, using normalized price as the dependent variable presumes that stores set prices as a percentage of cover price or equivalently as a percent markup over wholesale price. Wholesale prices are typically quoted as a fraction of the publisher's recommended price.
} 
willingness to accept lower gross margins on more expensive books and the price sensitivity or expectations of the buyers.

The regression results from Table 2 do not capture the competitive structure of the book market and differences between Amazon, Barnes and Noble, and Borders (the big three) and all other bookstores. ${ }^{14}$ We focus on these three bookstores, because in discussions with managers of other bookstores, managers identified these three as market leaders. Book availability by bookstore and category is presented in Table 3 . The big three stores carry nearly all of the books in the data set. Some other stores such as Booksamillion and Buy.com carry many of the books as well. Most other stores have limited selection, either across the board like Allbooks4less or in certain categories like Bookpool and Brian's Books.

In Table 4, we explore the effects of market structure on pricing behavior. ${ }^{5} \mathrm{We}$ define a market as the number of bookstores offering a price for a specific ISBN in a specific week. To characterize the competitive structure within a market, we track separately the number of big three bookstores and the number of what we will call, for lack of better terminology, fringe bookstores that provide a price. Looking at the control variables, the big three had substantially larger average discounts than fringe bookstores on both current and former bestsellers. The big three's discounts on hardcover and fiction were larger as well. The value of the constant indicates that the two types of stores had very similar prices on random, paperback nonfiction books. The effect of the week (time) variable on prices was small and positive but no longer significant for the big three

\footnotetext{
${ }^{14}$ This represents a natural grouping given that the big three account for the vast majority of online book sales. Other groupings are clearly possible given the heterogeneity of the other category. We explore this further in the section on firm strategy.

${ }^{15}$ Market structure is not exogenous, see Mazzeo (2000).
} 
and small, positive, and significant for the fringe bookstores, indicating that prices changed very little over time. This finding is consistent with the patterns of prices over time that we observe in Figure 1. 16

Given the baseline differences in prices between the big three and fringe bookstores, effects of additional competitors are remarkably similar. The way to interpret the effects of competitors is as follows. Same type and other type are in reference to the column heading. So, for instance, the same type for a big three firm would be another big three firm, and the same type for fringe bookstores would be another fringe bookstore. All effects are holding all other things constant, and changes in the competitive structure are aggregate. For a big three firm, the effect of adding the first same type competitor (i.e., another member of the big three) is to lower prices by 6.5 percent and the effect of adding the first other type competitor is to lower prices by 5.5 percent. For a fringe bookstore, the effect of the first competitor of the same type is to lower the price 7.8 percent and the effect of the first competitor of the other type is to lower the price 5.3 percent. The effect of the entry of the first and second competitors of the other type is to lower prices 4.6 percent for the big three and 6.2 percent for fringe bookstores. Note that the marginal effects of the second competitor of the other type are small, 0.6 percent increase for the big three and a 0.9 decrease for fringe bookstores. The coefficients on first and second same type for fringe bookstores and first through nth type for the big three are much larger - 11.7 and 10.4 percent - because they encompass the effect of adding on average 15 fringe bookstores.

\footnotetext{
${ }^{16}$ We had technical problems downloading the computer bestseller list in week nineteen, so we were unable to determine whether books were still on the bestseller list that week or not. This accounts for the gaps in Figures 1 and 2.
} 
The fact that the marginal effect of competitors is similar across the two types of bookstores is striking, because it suggests that the competitive fringe effectively disciplines the big three. We believe that this is caused by the aggressive pricing policies of a relatively small number of stores that carry 90 percent or more of the books in the sample. In markets where a relatively small number of stores sell a book, it is these stores that are repeatedly putting competitive pressure on the big three. We explore this issue in more detail below.

\section{Price Dispersion}

If costs are same across firms, then the standard intuition is that equilibrium price dispersion will be zero for a monopolist and zero or very small for competitive markets where most consumers are informed. In particular, we might think that consumers are likely to be informed about the price of New York Times bestsellers, since most internet and physical bookstores widely advertise their discounts on these books. Neither weighted nor unweighted standard deviation fit neatly into this story. Amazon and BarnesandNoble.com currently represent 80 percent or more of sales. As we will see below, their pricing strategies are very similar, so standard deviation weighted by sales would be small for all books. If the distribution of prices in the market is of interest, then unweighted standard deviation is an important metric.

Table 5 explores the relationship between unweighted standard deviation of prices and book characteristics. Standard deviation may depend on unit price, making it hard to interpret the first equation, so we will focus on the second regression. The baseline is a paperback, nonfiction, random book, and for that book the standard deviation as a 
fraction of normalized price is 0.11 . Sorenson (2000) found that the price and standard deviation of prescription drugs was lower for more frequently purchased items, a finding that is consistent with standard search theory. Thus it is somewhat surprising that New York Times bestsellers have much higher standard deviations than other books, 0.08 higher than the baseline of 0.11 . This effect is driven by some online stores, typically branches of physical stores, offering bestsellers at full price. The slightly higher standard deviations for computer bestsellers, former computer bestsellers, and former New York Times bestsellers are also a result of some stores charging full price.

In addition to interstore standard deviation, two other measures of standard deviation are potentially of interest - prices for a given book at a given store across time (intertemporal price dispersion), and within a category of books at a given bookstore at a given time (intracategory price dispersion). The average standard deviations for these measures are reported by category in Table 6 . Intertemporal variation is relatively low, suggesting that bookstores do not change their prices very often. This is consistent with the fact that the modal bookstore does not change the price of a book, except when the book goes off of the bestseller list. Intracategory variation is higher, but still relatively low as well, indicating that stores tend to use similar pricing rules for books in a given category. One surprise is the variation within New York Times bestsellers. This seems to be the result of two factors: discounts are often smaller for paperback bestsellers than for hardcover bestsellers, and some stores only discount the top ten titles, rather than the top fifteen.

In Table 7, we explore the effects of market structure on standard deviation. Holding competitive structure constant, there are striking differences between the two 
types of stores across the control variables. For the big three, the prediction that widely advertised books should have lower standard deviation of price seems to hold. Specifically, random books have the highest standard deviation and New York Times bestsellers have the lowest standard deviation. For fringe bookstores, advertising (or more generally greater competition) seems to lead to higher standard deviation. This result is driven by stores that tend to sell their books at full price or nearly full price offer bestsellers at high prices, but presumably sell very few copies. The effect of time is negligible for both types of stores. This finding is consistent with the patterns of prices over time that we observe in Figure 2.

Examining the effects of competitors, going from two to more than two competitors of the same type increases the standard deviation of own type prices. And adding the first competitor of the other type also increases the standard deviation of own type prices. The total effect of competitors is declining as we move for the big three from first to first and second to first through nth of the other type and as we move for fringe bookstores from first and second to first through nth of the other type. Thus, the marginal effect of another competitor is to lower the standard deviation. So at some point, as predicted, more competition does lead to lower standard deviation.

\section{Firm Level Strategies}

Thus far we have restricted discussion to aggregate patterns. In this section we turn to firm level pricing strategies. One approach would be to compute average prices for the stores in Table 3 by book category, but as Table 3 indicates, there is huge variability in what stores carry. To control for this problem, we ran regressions on 
normalized price by category using both store and book fixed effects. The coefficients on the store dummies for each category of book are presented in Table 8. 17

Based on selection and prices, we divided the stores in Table 8 into six types. 18 The six types are: i) the big three bookstores, ii) other full-line stores that offer low prices on New York Times bestsellers, iii) full-line stores that offer average prices on New York Times bestsellers, iv) full-line stores that charge close to full price for most books, v) stores with limited selection and very low prices, and vi) specialty bookstores. The first two types of stores are very similar in that they offer wide selection and low prices on New York Times bestsellers. Given the similarity of the second type's pricing policy to the big three's pricing policy, the second type is probably the part of the competitive fringe that is disciplining the pricing behavior of the big three. The third type also offers wide selection but offers less competitive prices on of current and former New York Times bestsellers. The fourth type is usually a physical store that sells books at full price and seems to be using the web as a form of advertising. The fifth type is a specialty store that specializes in remaindered books. ${ }^{10}$ The sixth type is a store that specializes in one or more categories of books. Examples include Brian's Books and Bookpool that specialize in computer books, Christianbooks that specializes in Christian books, and Cherry Valley that specializes in children's books.

Because of Amazon's dominant status in the online book industry, its prices tend to act as a focal point. Table 9 compares each store's prices with Amazon's prices to

\footnotetext{
${ }^{17}$ It is interesting to note that Barnes and Noble and Borders were offering 50 percent off of New York Times bestsellers in their online channel and at the same time were offering only 40 percent off of New York Times hardcovers and 30 percent off of New York Times paperbacks. This runs counter to the interesting thesis proposed by Png et al. (2000) that online stores should offer smaller discounts on bestsellers than offline stores because buyer switching costs are lower.

${ }^{18}$ This categorization is not unique in the sense that one could have finer or less fine categorization, but it helps structure the analysis.
} 
determine the frequency with which that store's prices are above, below, or equal to

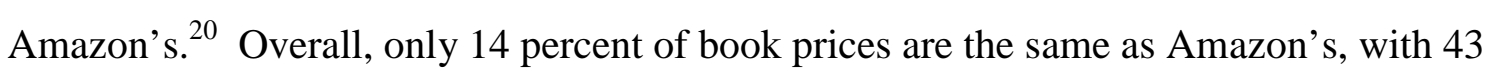
percent above Amazon's price and 43 percent below. Expanding the definition of equal to include prices that are within one percent of Amazon's expands this number to 21 percent and within $\$ 0.10$ expands it to 47 percent. Given that roughly two-thirds of the increase is coming from prices that were lower than Amazon's prices, it suggests that firms are marginally undercutting Amazon's price. This strategy ensures better placement if prospective customers search for prices either manually or using comparison-shopping engines.

The comparison in Table 9 highlights just how similar the strategies are for firms in the wide selection, low NYT category. The fraction of prices that are within $\$ 0.10$ of Amazon's prices ranges from a low of 70 percent for Buy.com to a high of 100 percent for Bookbuyer's Outlet. The results also suggest that despite their more limited discounts on New York Times bestsellers, some stores in the wide selection, average NYT category, notably Books.com and to a lesser extent BCY Book Loft, Fatbrain, and Kingbooks have similar prices to Amazon's for many titles. Not surprisingly the wide selection, close to full price group almost always is the same price or more expensive than Amazon. The limited selection, low prices group carries very few titles but is usually cheaper than Amazon. The limited selection, average to full prices group is more of a mixed bag. Most sites have fewer than 1,000 observations, reflecting their specialty status. For the somewhat broader range of titles they carry, Alldirect and Bookpool are

\footnotetext{
${ }^{19}$ The sale of remaindered books is discussed in more detail below.

${ }^{20}$ Thanks to Mike Smith for suggesting this measure to us.
} 
cheaper on average than Amazon and Pagelbook is more expensive than Amazon. The correlations presented in Table 10 tell a similar story.

Given the strategies documented in Tables 8-10, the question is how these strategies play out in the market. Based on their prices, the wide selection, full price stores seem to be using their websites primarily as a form of advertising. Andy Ross of Cody's Books confirmed that his site offered customers a way to check whether books were in stock at the physical store. If the person can not come to the store, books can be delivered in the San Francisco Bay Area, usually the next business day, via U.S. Mail. Computerlibrary, Powells, and Wordsworth are all physical stores that happen to have websites as well. The two internet-only stores in this group, Booksnow and Classbook do sell a wide selection of books, but seem to do so as an adjunct to their main line of business. For Booksnow (now ClickSmart), this is offering "services to magazines and Internet content web sites that want to outsource the sale of products, targeted to their readers' interests, that are mentioned in their print or electronic publications. ${ }^{, 21}$ For Classbook, its main line of business is textbooks.

The fifth type seems to be attracting traffic through low prices. Unsold books are eventually returned to the publisher. Publishers can resell these books as remaindered books. Remaindered books are sold by the pallet in mixed bundles and cannot be returned. Stores purchasing remaindered books do not typically know specific titles of books in a pallet. The price is often a function of weight or a fixed-fee per title and typically equals $10-20 \%$ of the publishers recommended price. Given their low wholesale cost, stores in this category can afford to offer customers discounts of 40-60 percent off of the publisher's recommended price and still make a profit. 
The sixth type represents a mix of strategies, some differentiation, some low prices, and some advertising. Alldirect and Bookpool are internet-only stores that specialize in low prices for the books they stock. Books4mom and Cherryvalleybooks are no longer operational. (Cherryvalleybooks was the website for the physical children's bookstore of the same name.) Brian's books is internet-only and specializes in computer books. It is a division of Davidson Computer Services and therefore may be an advertising or promotional tool. Christianbook began as a catalog book and now sells a wide selection of Christian products. It seems to be an example of successful differentiation. Hamiltonbook originated as and continues to be affiliated with a book catalog company of the same name. This too may be a source of differentiation. Page 1 book is the website of a physical store and seems to be primarily a means for the store to advertise.

The second group offers wide selection at low prices. Booksamillion.com is a familiar name because of its physical stores. Buy.com and Bookbuyers Outlet are both parts of larger internet-only stores that specialize in selling a variety of merchandise including books, music, videos, computer hardware, and computer software at low prices. In early 1999 Buy.com adopted a model that involved selling at wholesale and make revenue through advertising. Recent Securities and Exchange Commission filings indicate that Buy.com has moved away from this business model towards a model in which it makes positive margins on the merchandise that it sells. Despite having sold \$200 million worth of merchandise in the quarter ended September 2000, Buy.com's stock price recently hit an all time low, and it along with many other .coms may be at risk. Shopping.com has transformed from a bookstore into a shopbot.

\footnotetext{
${ }^{21}$ http://www.clicksmart.com/csinsert1.html
} 
The puzzle then is how the third type of firms is attracting and retaining customers. 1Bookstreet is a division of Soda Creek press. Although it does not have exceptionally low unit prices, it offers free shipping on all orders. In contrast, nearly all other booksellers charge $\$ 3.00-\$ 5.00$ to ship the first book and $\$ 0.90-\$ 1.00$ for each additional book. Alphacraze, A1 Books, and BCY Book Loft all seem to be following a strategy of being slightly cheaper than Amazon for most books. They are not, however, cheaper on average than Buy.com. All three appear to be internet-only stores, and two of the three explicitly identify their advantage as low prices. For instance A1 Books states, "We have the best prices, compared to any major online bookstore, on over 500,000 titles." 22 Alphacraze focuses on "price, selection, and service." a wide range of discounted items beyond books. Books.com was purchased by BarnesandNoble.com in the fall of 1999. Fatbrain is the online site for two physical stores that specialize in computer books. So although it has prices that are generally similar to Amazon's, it primarily serves individuals who are buying computer books or accessing its information exchange software. Kingbooks appears to have gone out of business. And Varsitybooks, as the name suggests, specializes in textbooks. So other than Kingbooks which has already failed, we would predict that the sites most at risk are those offering marginally lower prices and little else to differentiate their products Alphacraze, A1 Books, and BCY Book Loft.

\footnotetext{
${ }^{22}$ http://www.albooks.com

${ }^{23} \mathrm{http}: / /$ www.alphacraze.com/shop/customercare3.asp?tab=1\&acd=6BW5TMLRP3S92KX400J74RCQ8ST 0FSUD\&tabnew=1\#About us
} 


\section{Conclusion}

The level of competition that some observers predicted for mass-produced

physical goods on the Internet does not appear to have become a reality. ${ }^{24}$ Calculations of wholesale and order fulfillment costs - by far the largest components of marginal costs suggest that average net margins were in the $9-17$ percent range. ${ }^{25}$ Amazon, Barnes and Noble, and Borders and a number of other bookstores appear to have been selling New York Times bestsellers at or even below cost. Lower bound estimates of net margins for Amazon, Barnes and Noble, and Borders for the other four categories are, however, in the 7-18 percent range. ${ }^{26}$ Unweighted price and standard deviation were stable or rising between August 1999 and January 2000, suggesting that competition was not increasing. Sales by Amazon, Barnes and Noble, and Borders represent a very large fraction of all Internet book sales. For these stores price and standard deviation were stable, and standard deviation was small but not zero.

Competitive pressures appear to differ across categories of books in the way predicted by the search literature. Average unweighted prices were lowest for New York Times bestsellers and highest for random books, and the prices for bestsellers were lower than for former bestsellers. Although unweighted standard deviation is the highest - not the lowest - for New York Times bestsellers, this seems to be driven by some bookstores charging full price (and presumably selling very few copies). If we restrict our focus to

\footnotetext{
${ }^{24}$ We would like to also make comparisons between Internet and physical bookstores. Unfortunately, although we have fairly precise estimates of the prices in Barnes and Noble and Borders physical stores, large chains only sold 60 percent of the books sold in bookstores (Book Industry Study Group, 2000).

${ }^{25}$ Authors calculations using the gross margins in table 2 and assuming that order fulfillment costs were 15 percent of unit price, which is at the high end of the reported range.

${ }^{26}$ This assumes that any additional discounts these stores receive reflect the actual costs of providing the services and do not contribute to net margins. Bestseller sales are believed to represent less than 5 percent of overall sales.
} 
just the big three booksellers, prices and standard deviation are the lowest for New York Times bestsellers and highest for random books.

We observe some differentiation in selection and price. A number of branded and unbranded (or less well-branded) stores offer wide selection and competitive prices.

Some high priced stores do have a web presence, but seem to use the web primarily as a way to advertise, rather than as a vehicle for sales. A number of other stores specialize in particular product areas such as computer books, children's books, or remaindered books. The puzzle for us is stores that offer wide selection, but neither a brand name nor exceptionally competitive prices. As of March 2001, a number of these stores have gone out of business and the remainder appear to be at risk. 


\section{References}

“The real Internet revolution.” The Economist, Aug 21, 1999, pp. 53-54.

Arnold, M. A. "Costly Search, Capacity Constraints, and Bertrand Equilibrium Price Dispersion." International Economic Review, Feb. 2000, 41 (1), pp. 117-131.

Bailey, J "Intermediation and Electronic Markets: Aggregation and Pricing in Internet Commerce." Ph.D Thesis, Department of Electrical Engineering and Computer Science, MIT, May 20, 1998.

Benabou, R. "Search Market Equilibrium, Bilateral Heterogeneity, and Repeat Purchases." Journal of Economic Theory. 1993, 60, pp. 140-158.

Benham, L. "The Effect of Advertising on the Price of Eyeglasses." Journal of Law and Economics, October 1972, 15(2), pp. 337-52.

Bertrand, J. Theorie mathematique de la richess sociale. Journal des Savants, 499-508 (1883)

Book Industry Study Group. Press Release, June 2, 2000. Available at: http://www.bisg.org/pressrelease_june2_2000.html

Bookweb.org. "Industry Fair Trade Practices, 1999." http://www.bookweb.org/news/444.html

Brynjolfsson, E and M. Smith. "Frictionless Commerce? A Comparison of Internet and Conventional Retailers" Management Science 46(4) (April 2000): 563-585. Available at http://ecommerce.mit.edu/papers/friction/friction.pdf

Brynjolfsson, E and M. Smith. "The Great Equalizer? Consumer Choice Behavior at Internet Shopbots." Available at http://ecommerce.mit.edu/papers/tge/tge.pdf

Burdett, K. and M. G. Coles. "Steady State Price Distribution in a Noisy Search Equilibrium.” Journal of Economic Theory. 1977, 72, pp. 1-32.

Burdett, K. and K. L. Judd. "Equilibrium Price Dispersion.” Econometrica. July 1983, 51 (4), pp. 955-970.

Butters, G. R. "Equilibrium Distribution of Sales and Advertising Prices." Review of Economic Studies. Oct. 1977, 44(3), pp. 465-491.

Cady, J. F. "An Estimate of the Price Effects of Restrictions on Drug Price Advertising." Economic Inquiry 14(4) (Dec. 1976): 493-510 
Clay, K. , R. Krishnan, E. Wolff, and D. Fernandes. "Retail Strategies on the Web: Price and Nonprice Competition in the Online Book Industry." Working paper, 2000.

Available at: http://www.heinz.cmu.edu/ kclay/retailstrategies.pdf

Devine, D. G. and Marion, B. W. "The Influence of Consumer Price Information on Retail Pricing and Consumer Behavior." American Journal of Agricultural Economics, May 1979, 61(2), pp. 228-37.

Feldman, R. and J. Begun. "The Effects of Advertising: Lessons from Optometry." Journal of Human Resources, 1978, Supp. 13, pp. 247-62.

Feldman, R. and J. Begun. "Does Advertising of Prices Reduce the Mean and Variance of Prices?" Economic Inquiry, July 1980, 18(3), pp. 487-92.

Friedman, T. “Amazon.you.” New York Times, Feb 26, 1999; p. A21.

Glazer, A. “Advertising, Information, and Prices-A Case Study.” Economic Inquiry, October 1981, 19(4), pp. 661-71.

Hoynes, M. "The Impact of the Internet on Consumer Purchasing and Implications for Independent Booksellers.” Aug 6,1999. http://www.bookweb.org/home/news/btw/2244.html

Kaufman, L and S. Hansell. "Holiday Lessons In Online Retailing." New York Times, January 2, 2000, p. A1.

Kephart, J. and A. Greenwald. Shopbot Economics. Technical Report, IBM Institute for Advanced Commerce, 1998. Available at: www.research.ibm.com/infoecon/researchpapers.html

Kwoka, J. "Advertising and the Price and Quality of Optometric Services." American Economic Review, March 1984, 74(1), pp. 211-16.

Lee, H. G. "Do Electronic Marketplaces Lower the Price of Goods." Communications of the ACM. 1998, 41(1), pp. 73-80.

Mazzeo, M. "Price and Quantity Outcomes in Product Differentiated Oligopoly." Mimeo, Northwestern University, 2000.

Milyo, J. and J. Waldfogel. "The Effect of Price Advertising on Prices: Evidence in the Wake of 44 Liquormart." American Economic Review. December 1999, 89 (5), pp. 1081-96.

Png, I., Lee, T., and C. Yan. "The Competitiveness of On-Line vis a vis Conventional Retailing." Working paper, 2000. Available at: http://www.comp.nus.edu.sg/ ipng/Book.pdf 
Pratt, J. W., Wise, D. A., and R. Zeckhauser. "Price Differences in Almost Competitive Markets.” Quarterly Journal of Economics. May, 1979, 93 (2), pp. 189-211.

Rauh, M. T. “A Model of Temporary Search Market Equilibrium.” Journal of Economic Theory, 1977, 77, p. 128-153.

Salop, S. and J. Stiglitz. "Bargains and Ripoffs: A Model of Monopolistically Competitive Price Dispersion.” Review of Economic Studies, October 1977, 44 (3), pp. 493-510.

Salop, S. and J. E. Stiglitz. "The Theory of Sales: A Simple Model of Equilibrium Price Dispersion with Identical Agents." American Economic Review. Dec. 1982, 72(5), pp. 1121-1130.

Sorenson, A. T. "Equilibrium Price Dispersion in Retail Markets for Prescription Drugs." Journal of Political Economy. 2000, 108 (4), p. 833-850.

Stigler, G. "The Economics of Information.” Journal of Political Economy. June 1961, 69 (3), pp. 213-225.

Tedeschi, Bob. Online Shopping Better Than the Mall? New York Times on the Web. September 21, 1999.

http://search.nytimes.com/search/daily/bin/fastweb?getdoc+site+site+88429+2+wAA A+tedeschi\%7Esearch\%7Eengines

Unites States Census. Press Release, February 16, 2001. Available at: http://www.census.gov/mrts/www/current.html

Varian, H. “A Model of Sales.” American Economic Review. Sept. 1980, 70 (4), pp. 651659.

Wilde, L. L. and A. Schwartz. "Equilibrium Comparison Shopping." Review of Economic Studies. July 1979, 46 (3), pp. 543-553.

Wilke, J. “Technology.” Wall Street Journal. Jan 11, 1993; p. B1. 
Table 1: Summary Statistics

\begin{tabular}{|c|c|c|c|c|c|}
\hline & $\begin{array}{l}\text { NYT } \\
\text { Bestseller }\end{array}$ & $\begin{array}{l}\text { Former } \\
\text { NYT } \\
\text { Bestseller }\end{array}$ & $\begin{array}{l}\text { Computer } \\
\text { Bestseller }\end{array}$ & $\begin{array}{l}\text { Former } \\
\text { Computer } \\
\text { Bestseller }\end{array}$ & $\begin{array}{l}\text { Random } \\
\text { Book }\end{array}$ \\
\hline \# of observations & 25,681 & 28,342 & 26,870 & 16,661 & 63,879 \\
\hline Number of books & 136 & 122 & 82 & 69 & 181 \\
\hline Average weeks on list & 15.0 & NA & 15.6 & NA & NA \\
\hline Percent hardcover & $52.9 \%$ & $52.5 \%$ & $18.3 \%$ & $20.3 \%$ & $66.9 \%$ \\
\hline Percent fiction & $56.6 \%$ & $58.2 \%$ & $0.0 \%$ & $0.0 \%$ & $24.3 \%$ \\
\hline \multicolumn{6}{|c|}{ Prices } \\
\hline Publisher's rec. price & $\$ 17.28$ & $\$ 17.97$ & $\$ 43.08$ & $\$ 51.55$ & $\$ 37.92$ \\
\hline Unit price & $\$ 11.83$ & $\$ 13.48$ & $\$ 33.57$ & $\$ 40.23$ & $\$ 34.39$ \\
\hline Normalized price & 0.69 & 0.76 & 0.78 & 0.79 & 0.86 \\
\hline Wholesale price & $\$ 8.25$ & $\$ 9.43$ & $\$ 21.84$ & $\$ 28.85$ & $\$ 24.66$ \\
\hline Normalized wholesale price & 0.50 & 0.52 & 0.49 & 0.50 & 0.60 \\
\hline Normalized margin & 0.19 & 0.24 & 0.29 & 0.29 & 0.26 \\
\hline \multicolumn{6}{|c|}{ Price Dispersion } \\
\hline St. dev. of unit price & $\$ 6.63$ & $\$ 7.31$ & $\$ 17.31$ & $\$ 31.09$ & $\$ 31.08$ \\
\hline Diff. min and max price & $\$ 7.62$ & $\$ 6.06$ & $\$ 12.90$ & $\$ 14.12$ & $\$ 8.23$ \\
\hline St. dev. as $\%$ of avg. price & $27.7 \%$ & $17.8 \%$ & $15.6 \%$ & $14.0 \%$ & $12.9 \%$ \\
\hline Diff. as $\%$ of avg. price & $65.2 \%$ & $42.8 \%$ & $38.6 \%$ & $35.7 \%$ & $31.9 \%$ \\
\hline $\begin{array}{l}\text { Percent savings from not } \\
\text { using Amazon }\end{array}$ & $9.8 \%$ & $24.7 \%$ & $17.6 \%$ & $21.2 \%$ & $22.6 \%$ \\
\hline
\end{tabular}

Notes: The unit of observation is the price of a given book in a given store in a given week. Publisher's recommended price is the suggested retail price listed in Books in Print. Unit price is the price offered by a retailer on either its website or a shopbot that lists prices for several bookstores. Wholesale price is based on published terms that are quoted to the trade bookstores. Wholesale prices include estimated cost of shipping and include best possible discounts from publishers including any discounts for returnable books. Normalized price is unit price divided by the publishers recommended retail price. Normalized wholesale price is the wholesale price divided by the publisher's recommended retail price. Normalized margin is calculated as unit price minus wholesale price divided by publisher's recommended price. St. dev. is standard deviation and was computed by book for unit price and as a percentage of the mean price for that book and then averaged across books. Diff. min and max price is the difference between the minimum and maximum prices for a book and was computed by book using unit price and as a percentage of the mean price for that book and then averaged across books. Percent savings from not using Amazon represents the average percentage difference in unit price between Amazon and the lowest priced seller of a specific book in a specific week. 
Table 2: Fixed-Effects Regression of Price on Book and Sample Characteristics

\begin{tabular}{|c|c|c|c|}
\hline \multirow[b]{2}{*}{ Independent Variables } & \multicolumn{3}{|c|}{ Dependent Variable } \\
\hline & Unit price & $\begin{array}{l}\text { Normalized } \\
\text { price }\end{array}$ & $\begin{array}{l}\text { Normalized } \\
\text { gross margin }\end{array}$ \\
\hline Constant & $\begin{array}{l}1.71 * * * \\
(0.058)\end{array}$ & $\begin{array}{c}0.88^{* * *} \\
(0.001)\end{array}$ & $\begin{array}{c}0.25^{* * *} \\
(0.001)\end{array}$ \\
\hline Publisher's rec. price & $\begin{array}{l}0.89 * * * \\
(0.001)\end{array}$ & & \\
\hline NYT bestseller & $\begin{array}{l}-4.97 * * * \\
(0.057)\end{array}$ & $\begin{array}{l}-0.17 * * * \\
(0.001)\end{array}$ & $\begin{array}{l}-0.09 * * * \\
(0.001)\end{array}$ \\
\hline Former NYT bestseller & $\begin{array}{l}-7.10^{* * * *} \\
(0.058)\end{array}$ & $\begin{array}{l}-0.11 * * * \\
(0.001)\end{array}$ & $\begin{array}{l}0.01 * * * \\
(0.001)\end{array}$ \\
\hline Computer bestseller & $\begin{array}{l}-3.33 * * * \\
(0.053)\end{array}$ & $\begin{array}{l}-0.09 * * * \\
(0.001)\end{array}$ & $\begin{array}{l}-0.03 * * * \\
(0.001)\end{array}$ \\
\hline Former computer bestseller & $\begin{array}{l}-7.84 * * * \\
(0.066)\end{array}$ & $\begin{array}{l}-0.09 * * * \\
(0.001)\end{array}$ & $\begin{array}{l}0.01 * * * \\
(0.001)\end{array}$ \\
\hline Hardcover & $\begin{array}{l}-1.63 * * * \\
(0.038)\end{array}$ & $\begin{array}{l}-0.02 * * * \\
(0.001)\end{array}$ & $\begin{array}{l}-0.03^{* * *} \\
(0.001)\end{array}$ \\
\hline Fiction & $\begin{array}{l}-1.95^{* * *} \\
(0.043)\end{array}$ & $\begin{array}{l}-0.06^{* * *} \\
(0.001)\end{array}$ & $\begin{array}{l}-0.01 * * * \\
(0.001)\end{array}$ \\
\hline Week 9 bestseller & $\begin{array}{l}0.52 * * * \\
(0.049)\end{array}$ & $\begin{array}{c}0.01 * * \\
(0.001)\end{array}$ & $\begin{array}{l}-0.01 * * * \\
(0.001)\end{array}$ \\
\hline Week 17 bestseller & $\begin{array}{l}0.65^{* * * *} \\
(0.067)\end{array}$ & $\begin{array}{c}0.00 \\
(0.000)\end{array}$ & $\begin{array}{l}-0.001 \\
(0.002)\end{array}$ \\
\hline Time & $\begin{array}{c}0.05 * * * \\
(0.003)\end{array}$ & $\begin{array}{l}0.001 * * * \\
(0.000)\end{array}$ & $\begin{array}{l}0.001 * * * \\
(0.000)\end{array}$ \\
\hline Store fixed effects & Yes & Yes & Yes \\
\hline Number observations & 161,433 & 161,433 & 135,257 \\
\hline R-squared & 0.932 & 0.221 & 0.090 \\
\hline
\end{tabular}

Notes: Standard errors are in parentheses. Unit price is the price offered by a retailer on either its website or a shopbot that lists prices for several bookstores. Normalized price is unit price divided by the publishers recommended retail price. Normalized margin is calculated as unit price minus wholesale price divided by publisher's recommended price. Weekly observations for unit price, normalized price, and normalized margin are used. NYT Week 9 bestseller and Week 17 bestseller are dummy variables for books that enter the sample on the bestseller lists that become available on the $9^{\text {th }}$ and $17^{\text {th }}$ weeks of the sample, respectively. All regressions were estimated with store fixed effects. The omitted dummy variables are random books, paperback, and nonfiction. * = coefficient is significant at the 10 percent level, $* *=$ coefficient is significant at the 5 percent level, $* * *=$ coefficient is significant at the 1 percent level. 
Table 3: Percentage Availability of Books by Bookstore and Category of Book

\begin{tabular}{|c|c|c|c|c|c|}
\hline Store & $\begin{array}{l}\text { NYT } \\
\text { Bestseller }\end{array}$ & $\begin{array}{l}\text { Former } \\
\text { NYT } \\
\text { Bestseller }\end{array}$ & $\begin{array}{l}\text { Computer } \\
\text { Bestseller } \\
\text { Percentage }\end{array}$ & $\begin{array}{l}\text { Former } \\
\text { Computer } \\
\text { Bestseller }\end{array}$ & $\begin{array}{c}\text { Random } \\
\text { Book }\end{array}$ \\
\hline 1000's of Discount Books & 0 & 0 & 0 & 0 & 1 \\
\hline 1Bookstreet & 99 & 98 & 97 & 96 & 73 \\
\hline A1 Books & 99 & 97 & 95 & 98 & 75 \\
\hline Allbooks4less & 6 & 1 & 0 & 0 & 2 \\
\hline Alldirect & 41 & 38 & 25 & 26 & 29 \\
\hline Alphacraze & 90 & 89 & 89 & 94 & 64 \\
\hline Amazon & 99 & 98 & 98 & 98 & 84 \\
\hline BarnesandNoble.com & 100 & 100 & 100 & 100 & 86 \\
\hline BCY Book Loft & 90 & 90 & 74 & 57 & 39 \\
\hline Bookbuyer's Outlet & 58 & 40 & 62 & 38 & 52 \\
\hline Bookcloseouts & 5 & 1 & 1 & 0 & 0 \\
\hline Bookpool & 0 & 0 & 87 & 91 & 10 \\
\hline Books.com* & 38 & 21 & 43 & 23 & 43 \\
\hline Books4mom & 1 & 1 & 0 & 0 & 0 \\
\hline Booksamillion & 92 & 93 & 93 & 96 & 75 \\
\hline Booksnow & 54 & 44 & 61 & 44 & 55 \\
\hline Borders.com & 99 & 98 & 98 & 98 & 87 \\
\hline Brian's Books & 0 & 0 & 34 & 15 & 7 \\
\hline Buy.com & 98 & 94 & 94 & 97 & 75 \\
\hline Cherryvalleybooks & 8 & 2 & 0 & 0 & 4 \\
\hline Christianbook & 2 & 2 & 0 & 0 & 1 \\
\hline Classbook & 36 & 23 & 60 & 44 & 51 \\
\hline Codys books & 92 & 80 & 93 & 91 & 34 \\
\hline Computerlibrary & 76 & 73 & 82 & 65 & 33 \\
\hline Fatbrain & 90 & 97 & 97 & 99 & 79 \\
\hline Hamiltonbook & 11 & 14 & 0 & 2 & 8 \\
\hline Kingbooks & 99 & 96 & 95 & 97 & 76 \\
\hline Pagelbook & 41 & 38 & 24 & 24 & 30 \\
\hline Powells & 98 & 98 & 95 & 93 & 45 \\
\hline Shopping.com & 93 & 88 & 93 & 87 & 74 \\
\hline Varsitybooks & 63 & 55 & 59 & 66 & 58 \\
\hline Wordsworth & 53 & 58 & 54 & 50 & 44 \\
\hline
\end{tabular}

Notes: All of the above are .com sites. The .com has been removed unless there is significant potential for confusion with the physical site such as Borders.com and BarnesandNoble.com or the .com is an integral part of the name as in Books.com, Buy.com, and Shopping.com. Percentage availability is the number of sample ISBN's with prices reported by a bookstore in a week divided by the total possible number of sample ISBN's for the same week, averaged across all the weeks in the sample. Books.com was purchased by BarnesandNoble.com in the fall of 1999, so it dropped out of the sample part way through the period. 
Table 4: Normalized Price Regression for Two Types of Bookstores

\begin{tabular}{|clc|}
\hline Variable & Big Three & Fringe bookstores \\
Constant & $1.082^{* * *}$ & $1.064^{* * *}$ \\
& $(0.014)$ & $(0.011)$ \\
Effects of Competitors & & $-0.078^{* * *}$ \\
First same type & $-0.065^{* * *}$ & $(0.017)$ \\
& $(0.014)$ & $-0.117^{* * *}$ \\
First and second same type & $-0.070^{* * *}$ & $(0.017)$ \\
& $(0.014)$ & $-0.053^{* * *}$ \\
First other type & $-0.055^{* * *}$ & $(0.017)$ \\
& $(0.018)$ & $-0.062^{* * *}$ \\
First and second other type & $-0.049^{* *}$ & $(0.015)$ \\
& $(0.019)$ & $-0.060^{* * *}$ \\
First through nth other type & $-0.104^{* * *}$ & $(0.015)$ \\
Control Variables & $(0.014)$ & $-0.131^{* * *}$ \\
NYT bestseller & $-0.362^{* * * *}$ & $(0.006)$ \\
& $(0.011)$ & $-0.108^{* * *}$ \\
Former NYT bestseller & $-0.156^{* * *}$ & $(0.007)$ \\
& $(0.012)$ & $-0.073^{* * *}$ \\
Computer bestseller & $-0.137^{* * *}$ & $(0.006)$ \\
& $(0.010)$ & $-0.097^{* * *}$ \\
Former computer bestseller & $-0.122^{* * *}$ & $(0.008)$ \\
& $(0.013)$ & $-0.022^{* * *}$ \\
Hardcover & $-0.028^{* * *}$ & $(0.004)$ \\
& $(0.007)$ & $-0.054^{* * *}$ \\
Fiction & $-0.084^{* * *}$ & $(0.005)$ \\
Week & $(0.008)$ & $0.0005^{*}$ \\
& 0.001 & $(0.0003)$ \\
R-squared & $(0.004)$ & 6,959 \\
Number observations & 1,823 & 0.140 \\
\hline \hline
\end{tabular}

Notes: Standard errors are in parentheses. The dependent variable is the mean normalized price of a given book in a given week. Normalized price is unit price divided by the publishers recommended retail price. Unit price is the price offered by a retailer on either its website or a shopbot that lists prices for several bookstores. Weekly observations for unit price and normalized price are used. Observations have been weighted by the number of stores in the market to avoid overweighting observations from competitive markets. The big three are Amazon, Barnes and Noble, and Borders. Fringe bookstores refers to the other 29 stores in our data set. For a bookstore in the big three, the baseline would be a market with 1 big three bookstore and 0 fringe bookstores selling a particular book. For the big three, holding the number of fringe bookstores constant, first same type is the effect of going from 1 to 2 big three bookstores, and second same type is the effect of going from 1 to 3 big three bookstores. Similarly, for the big three, holding the number of big three bookstores constant, first other type is the effect of going from 0 to 1 fringe bookstores; second other type is the effect of going from 0 to 2 fringe bookstores; and additional other type is the effect of going from 0 to $\mathrm{N}$ fringe bookstores. The interpretation is reversed for fringe bookstores. NYT Week 9 bestseller and Week 17 bestseller are dummy variables for books that enter the sample on the bestseller lists that become available on the $9^{\text {th }}$ and $17^{\text {th }}$ weeks of the sample, respectively. $*=$ coefficient is significant at 
the 10 percent level, $* *=$ coefficient is significant at the 5 percent level, $* * *=$ coefficient is significant at the 1 percent level. 
Table 5: Regression of Standard Deviation of Price on Book and Sample Characteristics

\begin{tabular}{|lcc|}
\hline Variable & SD of unit price & SD of normalized price \\
Constant & $-0.23^{* * * *}$ & $0.11^{* * *}$ \\
Publisher's rec. price & $(0.085)$ & $(0.001)$ \\
& $0.09 * * *$ & \\
NYT bestseller & $(0.010)$ & $0.08^{* * *}$ \\
Former NYT bestseller & $1.57^{* * *}$ & $(0.002)$ \\
& $(0.099)$ & $0.01^{* * *}$ \\
Computer bestseller & $1.21^{* * *}$ & $(0.002)$ \\
& $(0.101)$ & $0.02^{* * *}$ \\
Former computer bestseller & $0.62^{* * *}$ & $(0.001)$ \\
& $(0.085)$ & $0.01^{* * *}$ \\
Hardcover & $0.90^{* * *}$ & $(0.002)$ \\
& $(0.107)$ & $0.00^{* * *}$ \\
Fiction & $0.50^{* * *}$ & $(0.001)$ \\
& $(0.059)$ & $0.01 * * *$ \\
Week 9 bestseller & 0.10 & $(0.001)$ \\
& $(0.067)$ & 0.00 \\
Week 17 bestseller & $-0.17 * * .001)$ \\
& $(0.087)$ & 0.00 \\
Time & -0.10 & $(0.002)$ \\
& $(0.114)$ & $-0.00^{*}$ \\
& $0.009 *$ & $(0.000)$ \\
Number observations & $(0.004)$ & \\
R-squared & & 8,544 \\
& 8,544 & 0.295 \\
\hline
\end{tabular}

Notes: Standard deviations of the estimates are in parentheses. Unit price is the price offered by a retailer on either its website or a shopbot that lists prices for several bookstores. Normalized price is unit price divided by the publishers recommended retail price. Standard deviations are calculated for either unit price or normalized price of a given book in a given week. Observations have been weighted by the number of stores in the market to avoid overweighting observations from competitive markets. NYT Week 9 bestseller and Week 17 bestseller are dummy variables for books that enter the sample on the bestseller lists that become available on the $9^{\text {th }}$ and $17^{\text {th }}$ weeks of the sample, respectively. The omitted dummy variables are random books, paperback, and nonfiction. $*=$ coefficient is significant at the 10 percent level, $* *=$ coefficient is significant at the 5 percent level, $* * *=$ coefficient is significant at the 1 percent level. 
Table 6: Standard Deviation of Normalized Price as a Fraction of Average Normalized Price by Category

\begin{tabular}{||lccc|}
\hline \hline & $\begin{array}{c}\text { Interstore } \\
\text { New York Times bestseller }\end{array}$ & $\begin{array}{c}\text { Intertemporal } \\
\text { Standard Deviation }\end{array}$ & $\begin{array}{c}\text { Intracategory } \\
\text { Standard Deviation }\end{array}$ \\
& 0.277 & 0.025 & 0.101 \\
Former NYT bestseller & $(0.030)$ & $(0.065)$ & $(0.073)$ \\
Computer bestseller & 0.178 & 0.045 & 0.117 \\
& $(0.044)$ & $(0.073)$ & $(0.035)$ \\
Former computer bestseller & 0.156 & 0.026 & 0.093 \\
& $(0.055)$ & $(0.045)$ & $(0.063)$ \\
Random books & 0.140 & 0.019 & 0.113 \\
& $(0.025)$ & $(0.037)$ & $(0.031)$ \\
& 0.129 & 0.027 & 0.159 \\
\hline
\end{tabular}

Notes: Normalized price is unit price divided by the publishers recommended retail price. Unit price is the price offered by a retailer on either its website or a shopbot that lists prices for several bookstores. Intertemporal standard deviation is the standard deviation of prices across time for a given book in a given store then averaged across all observations. Intracategory standard deviation is the standard deviation of prices across a book category (e.g. computer bestsellers) for a given store in a given week then averaged across all observations. Interstore standard deviations standard deviation of prices across stores for a given book in a given week then average across all observations. Average normalized prices are computed for the same groupings used to define intertemporal, intracategory, and interstore standard deviation. Standard deviations of standard deviations are given in parentheses. 
Table 7: Standard Deviation Regression for Two Types of Bookstores

\begin{tabular}{|c|c|c|}
\hline $\begin{array}{l}\text { Variable } \\
\text { Constant }\end{array}$ & $\begin{array}{l}\text { Big Three } \\
0.058 * * * \\
(0.012)\end{array}$ & $\begin{array}{c}\text { Fringe Bookstores } \\
0.055^{* * *} \\
(0.007)\end{array}$ \\
\hline \multicolumn{3}{|l|}{ Effects of Competitors } \\
\hline Second or greater & $0.012 * * *$ & $0.045 * * *$ \\
\hline same type & $(0.003)$ & $(0.006)$ \\
\hline \multirow[t]{2}{*}{ First other type } & $0.046 * * *$ & 0.002 \\
\hline & $(0.018)$ & $(0.007)$ \\
\hline \multirow[t]{2}{*}{ First and second other type } & $0.028 *$ & $0.021 * * *$ \\
\hline & $(0.016)$ & $(0.006)$ \\
\hline \multirow[t]{2}{*}{ First through nth other type } & -0.016 & $0.006 * * *$ \\
\hline & $(0.012)$ & $(0.006)$ \\
\hline \multicolumn{3}{|l|}{ Control Variables } \\
\hline \multirow[t]{2}{*}{ NYT bestseller } & $-0.033 * * *$ & $0.071 * * *$ \\
\hline & $(0.001)$ & $(0.001)$ \\
\hline \multirow[t]{2}{*}{ Former NYT bestseller } & -0.003 & $0.016 * * *$ \\
\hline & $(0.002)$ & $(0.001)$ \\
\hline \multirow[t]{2}{*}{ Computer bestseller } & $-0.006 * * *$ & $0.025 * * *$ \\
\hline & $(0.002)$ & $(0.001)$ \\
\hline \multirow[t]{2}{*}{ Former computer bestseller } & $-0.014 * * *$ & $0.007 * *$ \\
\hline & $(0.002)$ & $(0.001)$ \\
\hline \multirow[t]{2}{*}{ Hardcover } & $-0.005 * * *$ & $0.007 * * *$ \\
\hline & $(0.002)$ & $(0.001)$ \\
\hline \multirow[t]{2}{*}{ Fiction } & $0.016 * * *$ & $0.007 * * *$ \\
\hline & $(0.001)$ & $(0.001)$ \\
\hline \multirow[t]{2}{*}{ Week } & $-0.000 * * *$ & $0.000 *$ \\
\hline & $(0.000)$ & $(0.000)$ \\
\hline Number observations & 8,156 & 8,358 \\
\hline R-squared & 0.060 & 0.290 \\
\hline
\end{tabular}

Notes: The dependent variable is the standard deviation of the normalized price of a given book in a given week. Normalized price is unit price divided by the publishers recommended retail price. Unit price is the price offered by a retailer on either its website or a shopbot that lists prices for several bookstores. Weekly observations for unit price and normalized price are used. See the notes to Table 4 for definitions of same type, other type, big three, and fringe bookstores. The effects of competitors begins with second or greater of same type, because you need at least two firms of the same type (the baseline firm and the first of same type competitor) to calculate a standard deviation. NYT Week 9 bestseller and Week 17 bestseller are dummy variables for books that enter the sample on the bestseller lists that become available on the $9^{\text {th }}$ and $17^{\text {th }}$ weeks of the sample, respectively. $*=$ coefficient is significant at the 10 percent level, $* *=$ coefficient is significant at the 5 percent level, $* * *=$ coefficient is significant at the 1 percent level. 
Table 8: Average Normalized Price by Store

\begin{tabular}{|c|c|c|c|c|c|}
\hline & $\begin{array}{c}\text { NYT } \\
\text { Bestseller }\end{array}$ & $\begin{array}{c}\text { Former } \\
\text { NYT } \\
\text { Bestseller }\end{array}$ & $\begin{array}{l}\text { Computer } \\
\text { Bestseller }\end{array}$ & $\begin{array}{c}\text { Former } \\
\text { Computer } \\
\text { Bestseller }\end{array}$ & $\begin{array}{r}\text { Random } \\
\text { Book }\end{array}$ \\
\hline Store & \multicolumn{5}{|c|}{$\begin{array}{c}\text { Normalized Price } \\
\text { Big Three }\end{array}$} \\
\hline Amazon & 0.50 & 0.72 & 0.73 & 0.78 & 0.87 \\
\hline BarnesandNoble.com & 0.50 & 0.70 & 0.79 & 0.80 & 0.85 \\
\hline \multirow[t]{2}{*}{ Borders.com } & 0.50 & 0.69 & 0.77 & 0.79 & 0.83 \\
\hline & \multicolumn{5}{|c|}{ Wide Selection, Low NYT Prices } \\
\hline Bookbuyer's Outlet & 0.50 & 0.72 & 0.71 & 0.76 & 0.86 \\
\hline Booksamillion & 0.51 & 0.63 & 0.76 & 0.77 & 0.83 \\
\hline Buy.com & 0.47 & 0.61 & 0.71 & 0.71 & 0.76 \\
\hline \multirow[t]{2}{*}{ Shopping.com } & 0.54 & 0.66 & 0.72 & 0.74 & 0.82 \\
\hline & \multicolumn{5}{|c|}{ Wide Selection, Average NYT Prices } \\
\hline 1Bookstreet & 0.68 & 0.82 & 0.87 & 0.89 & 0.94 \\
\hline A1 Books & 0.71 & 0.71 & 0.71 & 0.74 & 0.81 \\
\hline Alphacraze & 0.64 & 0.68 & 0.67 & 0.69 & 0.78 \\
\hline BCY Book Loft & 0.73 & 0.72 & 0.76 & 0.77 & 0.81 \\
\hline Books.com & 0.67 & 0.72 & 0.78 & 0.79 & 0.85 \\
\hline Fatbrain & 0.67 & 0.71 & 0.74 & 0.76 & 0.85 \\
\hline Kingbooks & 0.74 & 0.74 & 0.73 & 0.74 & 0.84 \\
\hline \multirow[t]{2}{*}{ Varsitybooks } & 0.74 & 0.75 & 0.7 & 0.72 & 0.8 \\
\hline & \multicolumn{5}{|c|}{ Wide Selection, Close to Full Prices } \\
\hline Booksnow & 0.89 & 0.89 & 0.88 & 0.86 & 0.92 \\
\hline Classbook & 0.97 & 0.97 & 0.97 & 0.93 & 0.9 \\
\hline Codys books & 1.00 & 1.01 & 0.97 & 0.97 & 1.07 \\
\hline Computerlibrary & 1.00 & 0.99 & 0.96 & 0.99 & 1.07 \\
\hline Powells & 0.92 & 0.90 & 0.91 & 0.92 & 0.93 \\
\hline \multirow[t]{2}{*}{ Wordsworth } & 0.82 & 0.85 & 0.89 & 0.90 & 0.95 \\
\hline & \multicolumn{5}{|c|}{ Limited Selection, Low Prices } \\
\hline 1000's of Discount Books & & & & & 0.63 \\
\hline Allbooks4less & 0.43 & 0.55 & & & 0.43 \\
\hline \multirow[t]{2}{*}{ Bookcloseouts } & 0.47 & 0.42 & 0.47 & & \\
\hline & \multicolumn{5}{|c|}{ Limited Selection, Average to Full Prices } \\
\hline Alldirect & 0.62 & 0.64 & 0.61 & 0.64 & 0.75 \\
\hline Bookpool & & & 0.63 & 0.64 & 0.71 \\
\hline Books4mom & 0.63 & 0.64 & & & 0.76 \\
\hline Brian's Books & & & 0.81 & 0.82 & 0.82 \\
\hline Cherryvalleybooks & 0.89 & 0.92 & & & 0.89 \\
\hline Christianbook & 0.73 & 0.74 & & & 0.74 \\
\hline Hamiltonbook & 0.66 & 0.69 & & 0.75 & 0.63 \\
\hline Pagelbook & 0.99 & 1.00 & 0.97 & 0.96 & 0.99 \\
\hline
\end{tabular}

Notes: Average prices are the regression coefficients from the regression of normalized prices on store dummies with book fixed-effects. Normalized price is unit price divided by the publishers recommended retail price. Unit price is the price offered by a retailer on either its website or a shopbot that lists prices for several bookstores. 
Table 9: Price Comparisons with Amazon

\begin{tabular}{|c|c|c|c|c|c|c|c|c|c|c|}
\hline \multirow{4}{*}{$\begin{array}{l}\text { BarnesandNoble.com } \\
\text { Borders.com }\end{array}$} & \multirow{3}{*}{$\begin{array}{l}\text { Obs. } \\
3,907\end{array}$} & \multirow{2}{*}{\multicolumn{3}{|c|}{$\begin{array}{ll} & \text { Equal } \\
\text { Equal } & \text { Above Below }\end{array}$}} & \multicolumn{3}{|c|}{ Within $1 \%$} & \multicolumn{3}{|c|}{ Within $\$ 0.10$} \\
\hline & & & & & \multicolumn{2}{|c|}{$\begin{array}{c}\text { Equal Above } \\
\text { Big Three }\end{array}$} & Below & \multirow{2}{*}{$\begin{array}{l}\text { Equal } \\
87 \%\end{array}$} & \multirow{2}{*}{$\begin{array}{r}\text { Above } \\
7 \%\end{array}$} & \multirow{2}{*}{$\begin{array}{r}\text { Below } \\
6 \%\end{array}$} \\
\hline & & $55 \%$ & $14 \%$ & $32 \%$ & $77 \%$ & $11 \%$ & $11 \%$ & & & \\
\hline & 3,953 & $73 \%$ & $12 \%$ & $15 \%$ & $75 \%$ & $10 \%$ & $15 \%$ & $85 \%$ & $6 \%$ & $9 \%$ \\
\hline & \multicolumn{10}{|c|}{ Wide Selection, Low NYT Prices } \\
\hline Bookbuyer's Outlet & 1,488 & $95 \%$ & $3 \%$ & $2 \%$ & $95 \%$ & $3 \%$ & $2 \%$ & $100 \%$ & $0 \%$ & $0 \%$ \\
\hline Booksamillion & 3,492 & $54 \%$ & $10 \%$ & $36 \%$ & $65 \%$ & $10 \%$ & $25 \%$ & $76 \%$ & $7 \%$ & $18 \%$ \\
\hline Buy.com & 3,650 & $3 \%$ & $7 \%$ & $90 \%$ & $13 \%$ & $7 \%$ & $80 \%$ & $70 \%$ & $4 \%$ & $26 \%$ \\
\hline \multirow[t]{2}{*}{ Shopping.com } & 3,329 & $41 \%$ & $12 \%$ & $47 \%$ & $52 \%$ & $12 \%$ & $36 \%$ & $74 \%$ & $8 \%$ & $17 \%$ \\
\hline & \multicolumn{10}{|c|}{ Wide Selection, Average NYT Prices } \\
\hline 1Bookstreet & 3,739 & $3 \%$ & $89 \%$ & $8 \%$ & $4 \%$ & $88 \%$ & $8 \%$ & $24 \%$ & $70 \%$ & $6 \%$ \\
\hline A1Books & 3,833 & $3 \%$ & $32 \%$ & $65 \%$ & $6 \%$ & $32 \%$ & $63 \%$ & $58 \%$ & $27 \%$ & $15 \%$ \\
\hline Alphacraze & 3,397 & $4 \%$ & $27 \%$ & $69 \%$ & $4 \%$ & $27 \%$ & $69 \%$ & $48 \%$ & $18 \%$ & $34 \%$ \\
\hline BCYBookLoft & 2,778 & $7 \%$ & $36 \%$ & $56 \%$ & $7 \%$ & $36 \%$ & $56 \%$ & $67 \%$ & $32 \%$ & $2 \%$ \\
\hline Books.com & 1,005 & $0 \%$ & $34 \%$ & $66 \%$ & $59 \%$ & $34 \%$ & $8 \%$ & $78 \%$ & $18 \%$ & $4 \%$ \\
\hline Fatbrain & 3,667 & $24 \%$ & $26 \%$ & $50 \%$ & $57 \%$ & $26 \%$ & $18 \%$ & $65 \%$ & $23 \%$ & $12 \%$ \\
\hline Kingbooks & 3,756 & $0 \%$ & $52 \%$ & $48 \%$ & $1 \%$ & $52 \%$ & $47 \%$ & $64 \%$ & $29 \%$ & $7 \%$ \\
\hline \multirow[t]{2}{*}{ Varsitybooks } & 2,309 & $5 \%$ & $48 \%$ & $47 \%$ & $5 \%$ & $48 \%$ & $47 \%$ & $48 \%$ & $28 \%$ & $24 \%$ \\
\hline & \multicolumn{10}{|c|}{ Wide Selection, Close to Full Prices } \\
\hline Booksnow & 1,398 & $1 \%$ & $85 \%$ & $14 \%$ & $1 \%$ & $85 \%$ & $14 \%$ & $26 \%$ & $67 \%$ & $7 \%$ \\
\hline Classbook & 1,427 & $0 \%$ & $71 \%$ & $29 \%$ & $1 \%$ & $71 \%$ & $28 \%$ & $22 \%$ & $69 \%$ & $8 \%$ \\
\hline Codysbooks & 3,043 & $4 \%$ & $96 \%$ & $1 \%$ & $4 \%$ & $96 \%$ & $1 \%$ & $5 \%$ & $95 \%$ & $0 \%$ \\
\hline Computerlibrary & 2,047 & $1 \%$ & $98 \%$ & $0 \%$ & $1 \%$ & $98 \%$ & $0 \%$ & $4 \%$ & $96 \%$ & $0 \%$ \\
\hline Powells & 3,197 & $3 \%$ & $86 \%$ & $12 \%$ & $6 \%$ & $85 \%$ & $9 \%$ & $25 \%$ & $72 \%$ & $3 \%$ \\
\hline \multirow[t]{2}{*}{ Wordsworth } & 1,911 & $12 \%$ & $83 \%$ & $5 \%$ & $12 \%$ & $83 \%$ & $4 \%$ & $24 \%$ & $74 \%$ & $2 \%$ \\
\hline & \multicolumn{10}{|c|}{ Limited Selection, Low Prices } \\
\hline 1000'sofDiscountBooks & 18 & $0 \%$ & $0 \%$ & $100 \%$ & $0 \%$ & $0 \%$ & $100 \%$ & $17 \%$ & $0 \%$ & $83 \%$ \\
\hline Allbooks4less & 93 & $0 \%$ & $11 \%$ & $89 \%$ & $0 \%$ & $11 \%$ & $89 \%$ & $27 \%$ & $5 \%$ & $68 \%$ \\
\hline \multirow[t]{2}{*}{ Bookcloseouts } & 28 & $0 \%$ & $50 \%$ & $50 \%$ & $0 \%$ & $50 \%$ & $50 \%$ & $57 \%$ & $4 \%$ & $39 \%$ \\
\hline & \multicolumn{10}{|c|}{ Limited Selection, Average to Full Prices } \\
\hline Alldirect & 1,696 & $0 \%$ & $27 \%$ & $72 \%$ & $2 \%$ & $27 \%$ & $71 \%$ & $19 \%$ & $19 \%$ & $62 \%$ \\
\hline Bookpool & 1,157 & $0 \%$ & $8 \%$ & $92 \%$ & $2 \%$ & $8 \%$ & $90 \%$ & $24 \%$ & $0 \%$ & $76 \%$ \\
\hline Books4mom & 29 & $0 \%$ & $48 \%$ & $52 \%$ & $0 \%$ & $48 \%$ & $52 \%$ & $59 \%$ & $17 \%$ & $24 \%$ \\
\hline Brian'sBooks & 214 & $0 \%$ & $49 \%$ & $51 \%$ & $2 \%$ & $49 \%$ & $49 \%$ & $57 \%$ & $34 \%$ & $10 \%$ \\
\hline Cherryvalleybooks & 129 & $4 \%$ & $73 \%$ & $23 \%$ & $4 \%$ & $73 \%$ & $23 \%$ & $19 \%$ & $67 \%$ & $14 \%$ \\
\hline Christianbook & 25 & $4 \%$ & $40 \%$ & $56 \%$ & $48 \%$ & $40 \%$ & $12 \%$ & $56 \%$ & $36 \%$ & $8 \%$ \\
\hline Hamiltonbook & 297 & $21 \%$ & $32 \%$ & $47 \%$ & $44 \%$ & $32 \%$ & $24 \%$ & $49 \%$ & $28 \%$ & $22 \%$ \\
\hline Page1book & 1,667 & $7 \%$ & $84 \%$ & $9 \%$ & $8 \%$ & $83 \%$ & $9 \%$ & $14 \%$ & $81 \%$ & $5 \%$ \\
\hline Average & & $14 \%$ & $43 \%$ & $43 \%$ & $21 \%$ & $43 \%$ & $36 \%$ & $47 \%$ & $34 \%$ & $20 \%$ \\
\hline
\end{tabular}

Notes: Observations include only the unit prices that Amazon and the competitor list on the same day. Unit price is the price offered by a retailer on either its website or a shopbot that lists prices for several bookstores. Price comparisons within $1 \%$ are measured as $1 \%$ of Amazon's listed price for a specific ISBN on a specific day. Price comparisons within $\$ 0.10$ include those prices within $\$ 0.10$ of Amazon's listed price for a specific ISBN on a specific day. 
Table10: Individual Price Correlations between Amazon and Competing Online Booksellers

\begin{tabular}{|c|c|c|c|c|c|c|}
\hline \multirow[b]{3}{*}{ Store } & \multirow[b]{3}{*}{ Overall } & \multicolumn{2}{|r|}{ Former } & \multicolumn{2}{|r|}{ Former } & \multirow{3}{*}{$\begin{array}{r}\text { Random } \\
\text { Book }\end{array}$} \\
\hline & & \multirow{2}{*}{$\begin{array}{c}\text { NYT } \\
\text { Bestseller }\end{array}$} & NYT & Computer & Computer & \\
\hline & & & $\begin{array}{c}\text { Bestseller } \\
\text { Big } T\end{array}$ & $\begin{array}{l}\text { Bestseller } \\
\text { Three }\end{array}$ & Bestseller & \\
\hline BarnesandNoble.com & 0.88 & 0.56 & 0.71 & 0.55 & 0.85 & 0.88 \\
\hline \multirow{2}{*}{ Borders.com } & 0.85 & 0.49 & 0.57 & 0.57 & 0.67 & 0.83 \\
\hline & \multicolumn{6}{|c|}{ Wide Selection, Low NYT Prices } \\
\hline Bookbuyer'sOutlet & 0.98 & 0.79 & 1.00 & 0.98 & 1.00 & 1.00 \\
\hline Booksamillion & 0.82 & 0.45 & 0.33 & 0.42 & 0.47 & 0.89 \\
\hline Buy.com & 0.81 & 0.42 & 0.32 & 0.55 & 0.53 & 0.85 \\
\hline \multirow[t]{2}{*}{ Shopping.com } & 0.78 & 0.12 & 0.23 & 0.53 & 0.62 & 0.83 \\
\hline & \multicolumn{6}{|c|}{ Wide Selection, Average NYT Prices } \\
\hline 1Bookstreet & 0.78 & 0.18 & 0.44 & 0.50 & 0.68 & 0.80 \\
\hline A1Books & 0.70 & 0.33 & 0.45 & 0.52 & 0.63 & 0.81 \\
\hline Alphacraze & 0.65 & 0.17 & 0.44 & 0.33 & 0.77 & 0.74 \\
\hline BCY Book Loft & 0.38 & 0.54 & 0.52 & 0.58 & 0.72 & 0.34 \\
\hline Books.com & 0.84 & 0.38 & 0.48 & 0.55 & 0.86 & 0.87 \\
\hline Fatbrain & 0.68 & 0.18 & 0.30 & 0.67 & 0.68 & 0.76 \\
\hline Kingbooks & 0.66 & 0.62 & 0.17 & 0.40 & 0.75 & 0.75 \\
\hline \multirow[t]{2}{*}{ Varsitybooks } & 0.44 & 0.47 & -0.10 & 0.20 & 0.60 & 0.58 \\
\hline & \multicolumn{6}{|c|}{ Wide Selection, Close to Full Prices } \\
\hline Booksnow & 0.24 & 0.24 & 0.02 & 0.14 & 0.16 & 0.30 \\
\hline Classbook & -0.10 & 0.65 & 0.42 & 0.47 & 0.53 & -0.27 \\
\hline Codysbooks & 0.15 & 0.74 & 0.21 & 0.54 & 0.43 & 0.17 \\
\hline Computerlibrary & 0.14 & 0.80 & 0.14 & 0.49 & 0.40 & 0.11 \\
\hline Powells & 0.02 & 0.12 & 0.27 & 0.27 & 0.40 & -0.05 \\
\hline \multirow[t]{2}{*}{ Wordsworth } & 0.57 & 0.32 & 0.41 & 0.45 & 0.62 & 0.62 \\
\hline & \multicolumn{6}{|c|}{ Limited Selection, Low Prices } \\
\hline 1000'sofDiscountBooks & 0.30 & & & & & 0.20 \\
\hline Allbooks4less & -0.39 & -0.42 & 0.09 & & & 0.27 \\
\hline \multirow[t]{2}{*}{ Bookcloseouts } & 0.08 & 0.73 & 0.64 & & & -0.76 \\
\hline & \multicolumn{6}{|c|}{ Limited Selection, Average to Full Prices } \\
\hline Alldirect & 0.73 & 0.38 & 0.55 & 0.63 & 0.91 & 0.77 \\
\hline Bookpool & 0.72 & & & 0.57 & 0.63 & 0.35 \\
\hline Books4mom & -0.34 & 0.50 & 0.18 & & & -0.64 \\
\hline Brian’sBooks & 0.73 & & & 0.74 & 0.87 & 0.46 \\
\hline Cherryvalleybooks & 0.38 & -0.32 & 0.88 & & & 0.38 \\
\hline Christianbook & -0.02 & 0.54 & -0.62 & & & 0.52 \\
\hline Hamiltonbook & -0.05 & -0.65 & -0.23 & & & -0.04 \\
\hline Page1book & 0.12 & 0.48 & 0.16 & 0.67 & 0.36 & 0.14 \\
\hline
\end{tabular}

Notes: Correlations are individual correlations of unit prices between Amazon and a retailer listed for the identical ISBN's on the same day. Unit price is the price offered by a retailer on either its website or a shopbot that lists prices for several bookstores. 
Figure 1. Average Normalized Price by Book Category

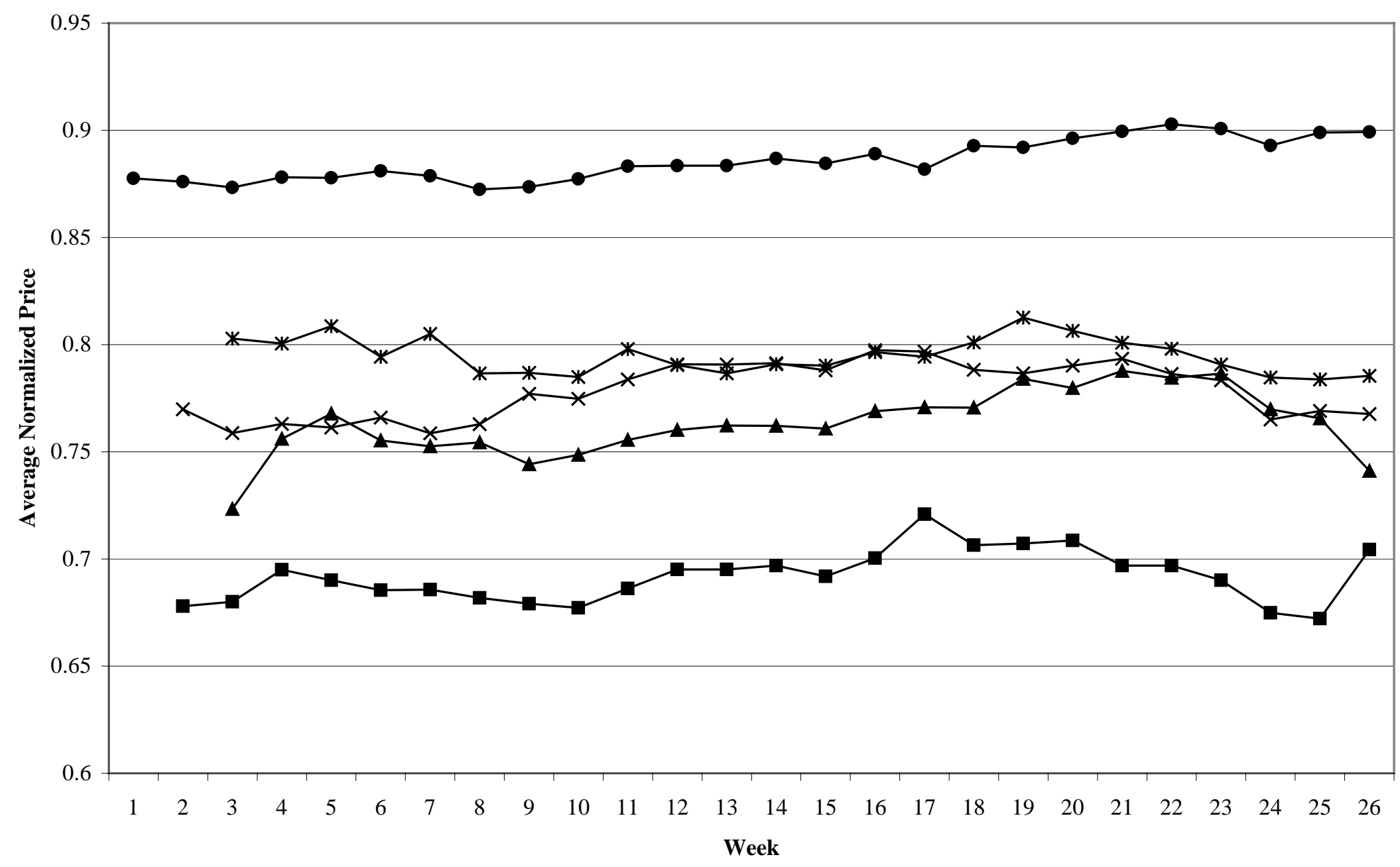

- New York Times Bestsellers $\longrightarrow$-Former New York Times Bestsellers $\rightarrow \leftarrow$ Computer Bestsellers $\rightarrow$ Former Computer Bestsellers 
Figure 2. Average Standard Deviation of Normalized Prices by Category

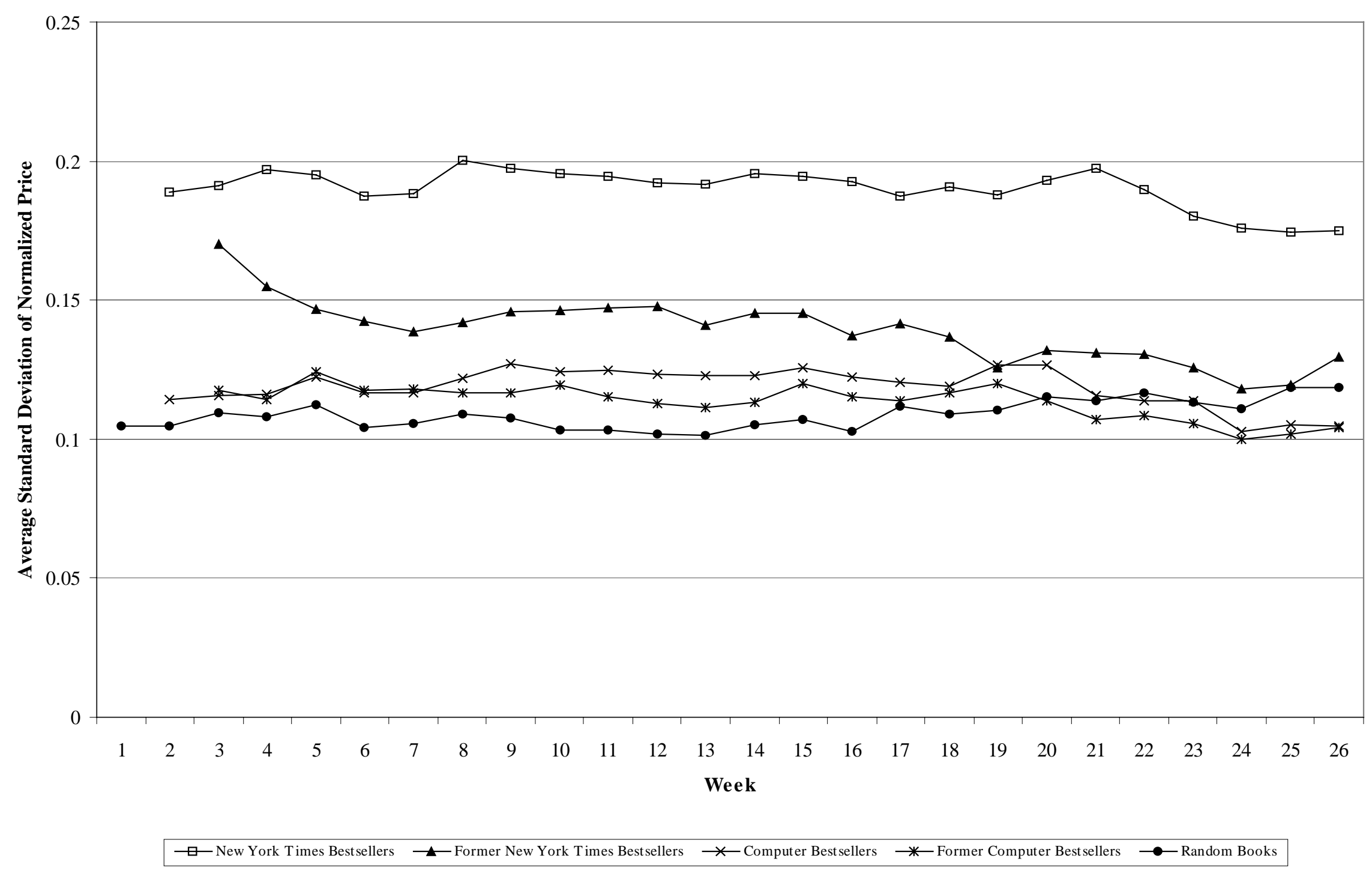


